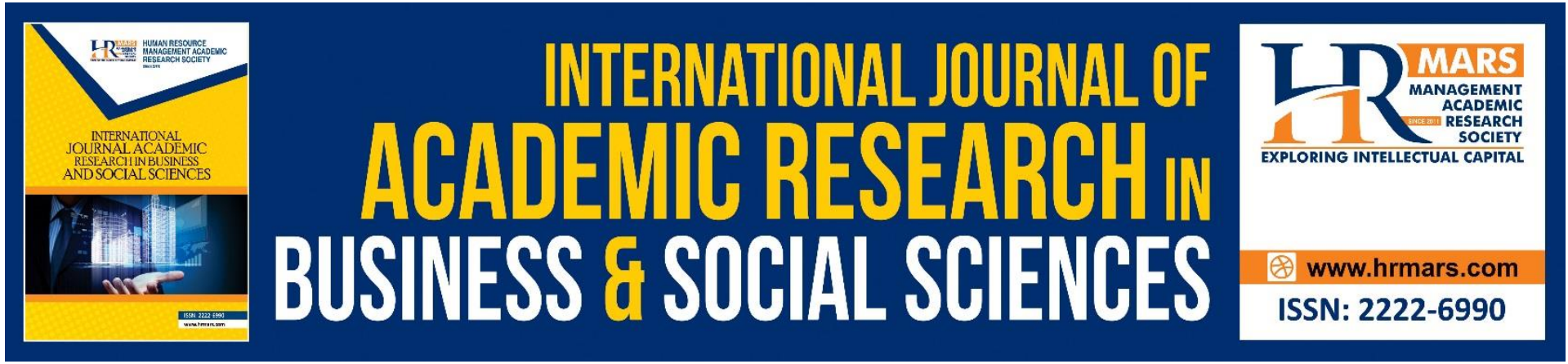

\title{
Information of Covid-19 on Ott Services Influences the Intention to Follow "The Stay at Home" Orders
}

\author{
Dzaa Imma Abdul Latiff \& Suhaila Kamal
}

To Link this Article: http://dx.doi.org/10.6007/IJARBSS/v11-i9/10797

DOI:10.6007/IJARBSS/v11-i9/10797

Received: 16 July 2021, Revised: 11 August 2021, Accepted: 29 August 2021

Published Online: 13 September 2021

In-Text Citation: (Latiff \& Kamal, 2021)

To Cite this Article: Latiff, D. I. A., \& Kamal, S. (2021). Information of Covid-19 on Ott Services Influences the Intention to Follow "The Stay at Home" Orders. International Journal of Academic Research in Business and Social Sciences, 11(9), 282-296.

Copyright: (c) 2021 The Author(s)

Published by Human Resource Management Academic Research Society (www.hrmars.com)

This article is published under the Creative Commons Attribution (CC BY 4.0) license. Anyone may reproduce, distribute, translate and create derivative works of this article (for both commercial and non-commercial purposes), subject to full attribution to the original publication and authors. The full terms of this license may be seen at: http://creativecommons.org/licences/by/4.0/legalcode

Vol. 11, No. 9, 2021, Pg. 282 - 296

http://hrmars.com/index.php/pages/detail/IJARBSS

JOURNAL HOMEPAGE

Full Terms \& Conditions of access and use can be found at http://hrmars.com/index.php/pages/detail/publication-ethics 


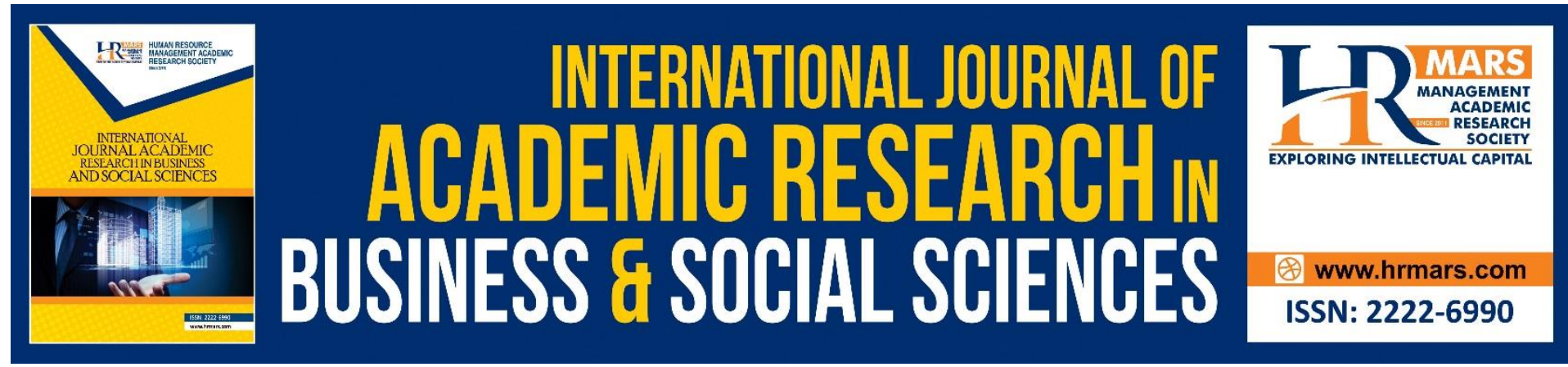

\title{
Information of Covid-19 on Ott Services Influences the Intention to Follow "The Stay at Home" Orders
}

\author{
Dzaa Imma Abdul Latiff ${ }^{1} \&$ Suhaila Kamal ${ }^{2}$ \\ Faculty of Communication and Media Studies, Universiti Teknologi MARA, Cawangan Negeri \\ Sembilan, Kampus Rembau \\ Email: dzaa17@uitm.edu.my
}

\begin{abstract}
Over the Top (OTT) services have become an essential and interesting medium in creating awareness on news and knowledge especially to the COVID-19 pandemic. OTT delivers audio, video streaming, voice and chat services. "Stay at Home" can be classified as health-related behaviour and this behaviour is originated from the intention to participate in that specific behaviour. In order for the citizen to follow the orders, a person needs to have the intention to obey the "Stay at Home" orders during the pandemic. News has reported that citizens detained at roadblocks gave reasons such as "just walking around, tired of staying at home, buying goods and various reasons". Thus, this study aims to examine the information of COVID-19 on OTT services that will affect people's intention to follow the "Stay at Home" orders. This study used theory of planned behaviour by Ajzen (1985) with three important variables that are attitude towards behaviour, subjective norms, and perceived control behaviours. 352 respondents were selected among the citizens in Klang district via online survey which was analysed through a covariance-based structural equation model. The findings supported the idea that information of COVID-19 on OTT services give impact to Klang's citizens to follow the "Stay at Home" orders. The hypotheses showed a positive and significant effect on the intention to follow the "Stay at Home" orders; attitude towards behaviour $(\beta=.267, p<.001)$, subjective norms $(\beta=.166, p<.05)$ and perceived behavioural control $(\beta=.261, p<.001)$. The results also improved our knowledge and understanding in a mission to inform OTT services can be as part of the educational approach in creating awareness and giving information. In conclusion, the research framework of theory of planned behaviour is a good theoretical medium to confirmed factors that influence citizens to follow the intention to "Stay at Home".
\end{abstract}

Keywords: OTT, "Stay at Home" Orders, COVID-19, Influence, Citizens

\section{Introduction}

Over the Top (OTT) services is a huge internet industry. It delivers audio and video streaming such as video on demand platforms, internet television, radio online, voice and chat services. It produces by the content service provider that is not accountable for the transmission of the signals to the end-user. The users can access the OTT services by just using the open internet 
protocol. In Malaysia, there are almost one million new users or streaming subscribers for OTT services as compared to last year which registered to 14.1 million users (Nielson, 2021). The rapid growth of OTT services or platforms is influenced by people's inclinations, technology, accessibility, convenience, etc. However, due to the COVID-19 pandemic, the usage of these platforms increased because users are enthusiastic or refuse to miss out on important information especially on health, the current statistics of COVID-19 new cases, number of deaths, vaccines, and more. The Media Partners Asia (2020) reported that total video streaming increased to $60 \%$ across Malaysia and other Southeast Asia countries such as Indonesia, Philippines, and Singapore between January to April in 2020. Most of them streaming the Internet television such as Tonton, MyKlik, Awani online, Bernama TV online, TVAlhijrahmedia.com, Netflix, etc. Meanwhile, users often used the chat services such as WhatsApp, Telegram and Messages that are used by the government's online platform especially the Malaysia National Security Council (NSC) and Ministry of Health (MOH). The pandemic started in early 2020 in Malaysia and one of the vital SOPs is to make everyone stay at home.

Awareness and social responsibility can be started with a self-contained Movement Control Order (MCO) by sitting at home and adhering to all Standard Operating procedures (SOP)s. "It is important to stay at home if there are no important matters outside just to break the COVID-19 chain more effectively". This verse is often expressed by The Director of Health, Tan Sri Dr. Noor Hisham Abdullah when having a press conference or and in the form of video on social media to remind people to abide by the SOP and together hit the curve of infection in this third wave (Affendy, 2020). Malaysia is facing a more challenging third wave of COVID19 following the emergence of several new variants that increase the contagion rate of the epidemic in the country. The country had recorded a sharp increase in cases over the past few weeks with COVID-19 positive cases reaching more than 4,000 cases a day (Hilm, 2021). Moreover, there are new variants of COVID-19 in Malaysia that were more violent as happened in India, United Kingdom, Brazil, South Africa, and other countries.

The Malaysian government initially took targeted action to curb the spread of the virus in the community. They have implemented the Movement Control Order (MCO) in several states and districts. The Enhanced Movement Control Order (EMCO) is also implemented in several areas such as in Terengganu where 21 districts have been identified (Rafidah, 2021). Meanwhile, almost all areas in the country turned into a red zone due to the virus spreading rapidly, with almost 70 percent of cases of infection occurring sporadically in the community. As of 21 June 2021, there are about 62,918 total active cases with 4,477 total deaths in Malaysia and Selangor is among the highest state that contributed to new cases 151,725 (MOH, 2021).

One of the efforts run by the Malaysian government is the introduction of the "Stay at Home" orders. Besides that, the spread of COVID-19 can be diminished through a set of specific attitudes and behavior such as " 3 W" (wash hand, wear a mask and worn) and $3 C$ (avoid crowded space, confine space, and close conversation). McEachan, Conner, Taylor, and Lawton (2011) explained that "Stay at Home" can be classified as health-related behavior. They also mentioned that the health-related behaviour originated from the intention to participate in that specific behavior. In order for the citizen to follow the orders, a person needs to have the intention to obey the "Stay at Home" orders during the pandemic. For 
example, news has reported that citizens detained at roadblocks on average gave unreasonable excuses such as "just walking around, tired of staying at home, buying goods and various reasons" (Bernama, 2020, Mac 19). A teenager aged 18 years old was compound for violating the EMCO. He has disobeyed the orders to exit and enter the EMCO area without police permission by exiting obstacles and barbed wire installed in the housing area (Asrol Awang, 2021). Meanwhile, a senior citizen was also fined because of violating the SOP during EMCO for reasons such as "feeling hot at home and wanting to go for a walk" (Abdul Rashid, 2021). Despite that, less study has been conducted or discussed regarding this topic. Previous studies are more to people's knowledge, awareness, and attitude towards the COVID-19 pandemic (Zhong et al., 2020; Martin Guo, 2020 \& Fan et al., 2018). Therefore, this study aims to examine the information of COVID-19 on OTT services that will affect citizens' behavioural intention to follow the "Stay at Home" orders.

\section{Literature Review}

\section{Theory of Planned Behavioural}

Theory of Planned Behaviour signifies a relationship between beliefs and behaviours. This theory was developed by Ajzen (1985). It was an extension of the theory known as Theory of Reasoned Action (TRA) by Azjen and Fishbein (1980), due to the "inability to deal with behaviours over which individuals have incomplete volitional control" (Ilham and Kamariah 2012 , p. 63). The theory explained that a person's performing a particular behaviour is decided by his or her own intention to perform that behaviour. In this study, attitude towards the behaviour subjective norms in engaging the behaviour, and perceived behaviour control are believed to influence the intention to "Stay at home" behaviour. This theory does not state the specific beliefs associated with certain behaviour, thus influencing those beliefs is depends on the researcher's selection or choice. "The more favourable the attitude and subjective norm, and the greater the perceived behavioural control over a certain behaviour, the stronger would be a person's intention to perform the behaviour in question" (Magdelene, Ramayah \& Hanuddin (2014, p. 188). Due to its relative resilience, this theory has gained much support in many fields such as psychology, health, sociology, marketing, consumer behaviour, and other disciplines. As shown in figure 1, the dependent variable (behavioural intention) is influenced directly by the independent variables which are represented by a) attitude towards the behaviour b) subjective norms and c) perceived behaviour control.

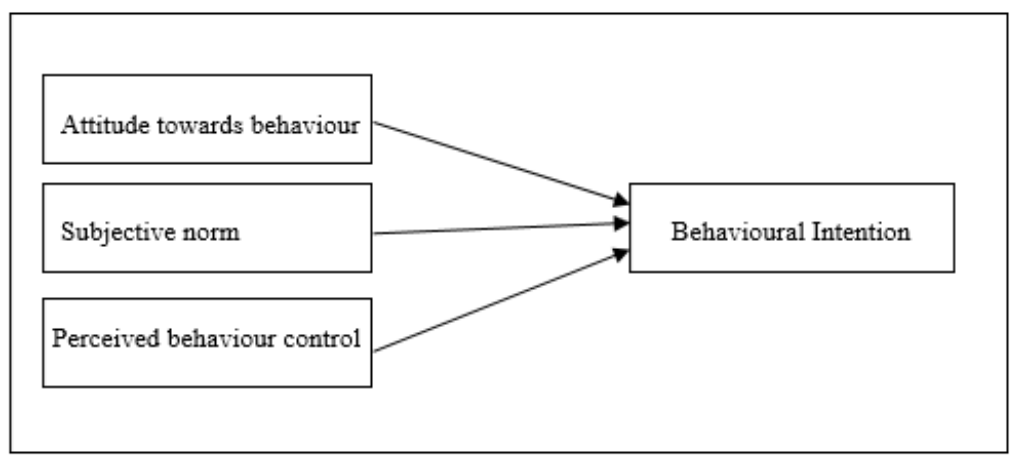

Figure 1: Research Framework 


\section{Attitude towards Behaviour (ATB)}

Attitude toward a behaviour is the extent to which the execution of that behaviour is rated either positive or negative. That will be determined by the entire set of existing behavioural beliefs that link the behaviour to a variety of other outcomes and characteristics. Attitude indicates a person's assessment and beliefs about the important consequences of implementing a behavior. Before determining to participate in a particular behavior, one tends to evaluate the advantages and costs caused by that behavior. So, when a person has a positive attitude towards a particular behavior, he or she tends to show the intended behavior in question (Ajzen, 1991; Han, Hsu \& Sheu, 2010). Earlier literature has recommended that attitude is among the most important factors influencing the behaviours. Studies showed that there is a significant relationship in intention to use online banking (Safeena, Kammani, \& Hundewale, 2013), internet purchasing (Ilham \& Kamariah, 2012), halal food purchasing intention (Ali, Xiaoling, Sherwani \& Ali, 2017), healthy menu selection (Kim, Kim, Choi \& Ham, 2018) and intention for healthy nutrition (Ates, 2019). Thus, attitude towards behaviour can be a significant indicator of intention to follow the "Stay at Home" orders.

\section{Subjective Norm (SN)}

The next determinant factor of behavioural intention is subjective norms that signify the belief that normative norms of others are important such as families, close friends, coworkers, or business partners (Ajzen, 2002). The theory stands that a person's motivation to participate in a certain behavior, will be mostly decided by the perceived preferences of her important referents. It can be argued that subjective norm is a person's perception of social expectation for applying or adopting certain behavior. In this study, the subjective norm can be defined as a person's perception that "important" people nearby would follow the "Stay at Home" orders during the outbreak. Therefore, if a person sees that social pressure to follow the "Stay at Home" orders on COVID-19 is high, she/he will be more likely to intend to do so. Previous studies have found positive and significant relationships such as a study on hiring Malaysian with disabilities (Magdalene et al., 2015), mobile health service (Zhang, Liu, Wang \& Wang, 2019), healthful diet (Close et al., 2018) and "Safer at home" study (Micheal, Daniel, and Charles, 2020). Therefore, the subjective norm of a current study can be a significant factor for intention to follow the "Stay at Home" orders.

\section{Perceived Behavioural Control (PCB)}

The last determinant factor is perceived behavioural control. It is perceived as ease or difficulty in executing a behaviour (Ajzen, 1991). Assessing behavioural control is considered "a perception of how a person controls the factors that can facilitate or constrain the actions required to deal with a particular situation" (Han et al., 2010, p, 604). It is an accurate picture of behavioral control policies, the notion of behavioural control can, along with intention, be used to predict behaviour. Previous research reported that when a person has less control over his or her actions due to lack or absence of necessary resources, his or her behavioural intentions will be reduced even if there are positive attitudes or helpful norms that support the intended behaviour (Han et al., 2010). Previous research also found positive connections between perceived behavioural control and intention to adopt internet banking (Safeena et al., 2013), to consume healthy nutrition (Ates, 2019) and to follow the "Stay at Home" orders during COVID-19 pandemic in Indonesia (Sik Sumaedi, 2020). Therefore, perceived behavioural control is among the important variables that can clarify the intention to follow the "Stay at Home" orders. 


\section{Behavioural Intention (BIN)}

Behavioural intention can be identified as the likelihood of engaging in a particular behaviour. And the great predictor of behaviour is intention. This theory claimed that behavioural intention indicates how strong a person's intention is in trying and how much effort he or she is willing to make in order to perform that behaviour (Ajzen, 1991). As a result, the intention to follow the "Stay at Home" orders during the outbreak was the strong willingness of Malaysian citizens to follow the orders. This willingness or commitment is indicated over by how much effort he or she is willing to put in.

Thus, the researchers would like to investigate the relationship between the information of COVID-19 on OTT services influences the intention to follow the "Stay at Home" orders as below:

$\mathrm{H}_{1}$ : Attitude toward the behavior of following the "Stay at Home" orders positively influence the intention to follow the "Stay at Home" orders during the pandemic

$\mathrm{H}_{2}$ : Subjective norm positively affects the intention to follow the "Stay at Home" orders during the pandemic.

$\mathrm{H}_{3}$ : Perceived behavioral control positively affects theintention to follow the "Stay at Home" orders

\section{Methodology}

\section{Sample and Statistical Procedure}

A cross-sectional, online survey was conducted among citizens of Klang District in Selangor during the first week of June 2021 ( $1^{\text {st }}$ June 2021 until $6^{\text {th }}$ June 2021). This study used convenience sampling and was open to all respondents in Klang but excluded frontliners and those who worked under the essential sectors. Klang is one of the 14 cities in Malaysia and was rank as number 3, with highest population. As of 2021, a total number of citizens in Klang is 1,055,207 (Population Hub, 2021). Klang has been chosen as one of the study locations due to a number of COVID-19 cases that increased rapidly at the end of April 2021. Between $2^{\text {nd }}$ April until $15^{\text {th }}$ April, the number of new cases was 825 and towards 15 May 2021, the number increased to $4040(\mathrm{MOH}, 2021$, May 15). In total, 386 online questionnaires were administered. However, after data screening, 34 responses were removed due to incomplete submissions and the final sample was 352. According to Hair (2010), sample in a range of 150400 is stable when using Structural Equation Model (SEM). The data were entered and analyzed using SPSS and Amos version 23.

Table 1 shows the profile of respondents based on the survey. Most respondents are female (68\%), with most of the age between 31 to 40 years old (33\%). Malays are among the highest rate (50\%) and most of them are married (48\%). Meanwhile, the highest education levels are among the degree holders (41\%) with the government sector is the highest response rate (34\%). Most of them earned between RM1,000-RM2000 and RM3000-RM4000 (17\%). As for the question regarding "how much time the respondents spend on OTT services daily in order to get the news or information of COVID-19?", majority of them spent between 15 minutes to 30 minutes (47\%), followed by less than 15 minutes (28\%) and one to two hours (10\%). Meanwhile, respondents preferred to use Telegram by NCS (23\%), Twitter (21\%) and Facebook (10\%) as compared to WhatsApp (9\%), Instagram (9\%), Awani online (8\%), Free TV online (8\%), and others. 
Table 1: Distribution of OTT user by profile $(n=352)$

\begin{tabular}{|c|c|c|c|c|c|}
\hline Profile & $\begin{array}{l}\text { Frequenc } \\
y\end{array}$ & $\begin{array}{l}\text { Percentage } \\
\text { (\%) }\end{array}$ & Profile & Frequency & $\begin{array}{l}\text { Percenta } \\
\text { ge (\%) }\end{array}$ \\
\hline Gender & & & Occupation & & \\
\hline Male & 114 & 32 & Private sector & 97 & 27 \\
\hline Female & 238 & 68 & $\begin{array}{l}\text { Government } \\
\text { sector }\end{array}$ & 119 & 34 \\
\hline & & & Self employed & 44 & 13 \\
\hline Age & & & Pensioner & 15 & 4 \\
\hline $18-20$ & 27 & 7 & Student & 62 & 18 \\
\hline $21-30$ & 97 & 28 & Unemployed & 15 & 4 \\
\hline $31-40$ & 115 & 33 & & & \\
\hline $41-50$ & 90 & 26 & $\begin{array}{l}\text { Time spent on } \\
\text { OTT }\end{array}$ & & \\
\hline$\geq 51$ & 23 & 6 & $\begin{array}{l}\text { Less than } 15 \\
\text { minutes }\end{array}$ & 98 & 28 \\
\hline & & & $\begin{array}{l}15 \text { minutes } 30 \\
\text { minute }\end{array}$ & 167 & 47 \\
\hline Race & & & $\begin{array}{l}30 \text { minutes to } 1 \\
\text { hour }\end{array}$ & 27 & 8 \\
\hline Malay & 178 & 50 & 1 hour to 2 hours & 34 & 10 \\
\hline Chinese & 91 & 26 & $\begin{array}{l}\text { More than } 2 \\
\text { hours }\end{array}$ & 26 & 7 \\
\hline Indian & 69 & 20 & & & \\
\hline Other & 14 & 4 & Platform & & \\
\hline & & & Telegram NCS & 82 & 23 \\
\hline Income & & & Twitter & 73 & 21 \\
\hline $\mathrm{Nil}$ & 45 & 13 & Facebook & 34 & 10 \\
\hline$\leq 1000$ & 50 & 14 & Whatsapp & 31 & 9 \\
\hline $1001-2000$ & 61 & 17 & Instagram & 31 & 9 \\
\hline $2001-3000$ & 53 & 15 & Awani online & 30 & 8 \\
\hline $3001-4000$ & 59 & 17 & Free TV online & 30 & 8 \\
\hline $4001-5000$ & 36 & 10 & MySejahtera & 21 & 6 \\
\hline$\geq 5000$ & 48 & 14 & $\mathrm{MOH}$ website & 20 & 6 \\
\hline Status & & & & & \\
\hline Single & 154 & 44 & & & \\
\hline Married & 170 & 48 & & & \\
\hline Divorce & 28 & 8 & & & \\
\hline Education & & & & & \\
\hline $\begin{array}{l}\text { Certificate/PMR/S } \\
\text { PM }\end{array}$ & 96 & 27 & & & \\
\hline Diploma & 86 & 24 & & & \\
\hline Degree & 144 & 41 & & & \\
\hline Master & 20 & 6 & & & \\
\hline Ph.D & 6 & 2 & & & \\
\hline
\end{tabular}




\section{Instruments and Reliability}

The instruments used were adapted from past research studies on health-related behaviour. A 15-item survey instrument was adopted and modified. The questions also included demography items and OTT usage. Respondents were asked about their experiences of getting information regarding COVID-19 from NSC and MOH on the OTT services. How these messages influence their behaviour to follow the "Stay at Home" orders such as a) attitude towards behaviour b) subjective norms and c) perceived behavioural control towards the behavioural intention to follow the "Stay at Home" orders.

Table 2 shows the allocation of instruments, items, reliability test, standardized item loadings, average variance extracted (AVE), composite reliability (CR), and Cronbach alpha (CA). The items used four Likert scales. The instruments were adopted by Peters and Templin (2010) and Liu et al. (2018) for items Behavioural Intention; Sumaedi et al. (2016) and Zhang et al. (2020) for item Attitude towards Behaviour to follow the "Stay at Home" orders; Peters and Templin (2010) and Bao et al. (2017) for item Subjective Norms and lastly Sumaedi et al. (2016) and Bao et al. (2017) for item Perceived Behavioural Control.

Before the questionnaires were distributed to the citizens, researchers will seek help from the experts to confirm that the items of an assessment or instrument are appropriate to the targeted study and objectives. The pre-test had been conducted among 30 students in the Degree programme. The results of the reliability analysis were presented in Table 2 to show that the reliability test is meet after some adjustments or reworded have been made to avoid misunderstanding when the respondents attempted the questionnaire. The factor loading for each item should be .6 or higher and must be positive (Hair et al., 2010). It is essential to conduct Average Variance Extracted (AVE) for each construct to measure the validity. Most of the factor loadings were larger than 0.6. The AVEs for all constructs exceed .5 (Fornell and Larcker, 1981), and CRs exceed .6. (Hair et al., 2010). 
Table 2: Instruments, standardized item loadings, CA values AVE, and CR

\begin{tabular}{|c|c|c|c|c|c|c|c|}
\hline Factor & Instrument & Item & $\begin{array}{l}\text { ltem } \\
\text { loadings } \\
\geq .60\end{array}$ & $\begin{array}{l}C A \geq .70 \\
\text { Pilot } \\
\text { Test }\end{array}$ & $\begin{array}{l}C A \geq .70 \\
\text { Field } \\
\text { Test }\end{array}$ & AVE $\geq .5$ & $C R \geq .6$ \\
\hline $\begin{array}{l}\text { Attitude } \\
\text { towards } \\
\text { behaviour of } \\
\text { following the } \\
\text { "Stay at Home" } \\
\text { orders }\end{array}$ & $\begin{array}{l}\text { Sumaedi et } \\
\text { al. (2016) and } \\
\text { Zhang et al. } \\
(2020)\end{array}$ & $\begin{array}{l}\text { ATB1 } \\
\text { ATB2 } \\
\text { ATB3 }\end{array}$ & $\begin{array}{l}.927 \\
.933 \\
.756\end{array}$ & .718 & .897 & .767 & .907 \\
\hline $\begin{array}{l}\text { Subjective } \\
\text { Norms }\end{array}$ & $\begin{array}{l}\text { Peters and } \\
\text { Templin } \\
(2010) \text { and } \\
\text { Bao et al. } \\
(2017)\end{array}$ & $\begin{array}{l}\text { SN1 } \\
\text { SN2 } \\
\text { SN3 }\end{array}$ & $\begin{array}{l}.813 \\
.884 \\
.903\end{array}$ & .799 & .844 & .753 & .901 \\
\hline $\begin{array}{l}\text { Perceived } \\
\text { Behavioural } \\
\text { Control }\end{array}$ & $\begin{array}{l}\text { Sumaedi et } \\
\text { al. }(2016) \text { and } \\
\text { Bao et al. } \\
(2017)\end{array}$ & $\begin{array}{l}\text { PCB1 } \\
\text { PCB2 } \\
\text { PCB3 }\end{array}$ & $\begin{array}{l}.912 \\
.927 \\
.788\end{array}$ & .807 & .893 & .771 & .909 \\
\hline $\begin{array}{l}\text { Behavioural } \\
\text { Intention }\end{array}$ & $\begin{array}{l}\text { Peters and } \\
\text { Templin } \\
(2010) \text { and } \\
\text { Liu et al. } \\
(2018)\end{array}$ & $\begin{array}{l}\text { BIN1 } \\
\text { BIN2 } \\
\text { BIN3 }\end{array}$ & $\begin{array}{l}.839 \\
.885 \\
.882 \\
\text { Meyer-Olkin } \\
<0.001) .\end{array}$ & (KMO) & .880 & .755 & .902 \\
\hline
\end{tabular}

* Cronbach alpha (CA), average variance extracted (AVE) and composite reliability (CR)

Next, the correlation of each construct has also been examined (Fornell and Larcker, 1981) (see Table 3). The results indicated that the square root of AVE for each construct was greater than the correlations between itself and all other constructs Lee and Kozar, (2008). implying that there existed discriminant validity for each construct. In addition, the variance of each construct was larger with itself than with other constructs and exceeded the acceptable level of .5.

Table 3: Measurement Model: Discriminant Validity and Correlations

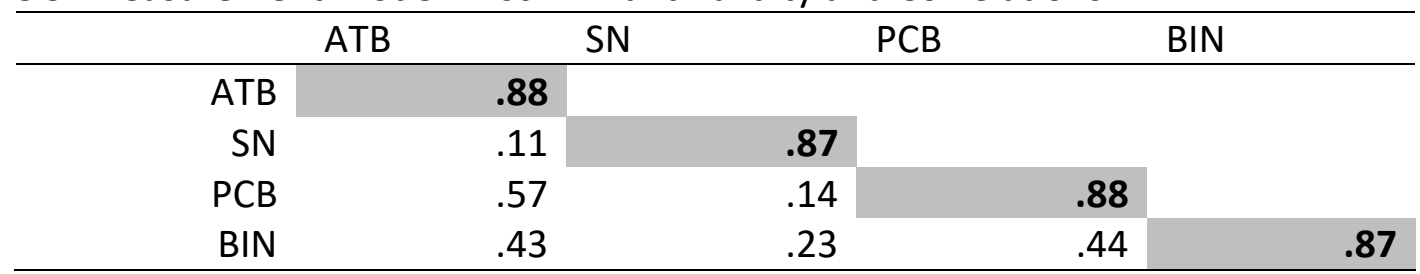

Note: Diagonal shadow is the square root of AVE

\section{The Measurement Model}

Three categories of model fit are normally used to assess a model fit in SEM. These are a) absolute fit, b) incremental fit and c) parsimonious fit. Referring to table 4, the absolute fit reported that $\chi 2$ test showed $p$-value $=.000$. The $(\chi 2 / d$. f) was below 3.0 showed acceptable fit 
and the goodness of index (GFI) exceeded the suggested value of .9 or adequate fit (Joreskog \& Sorbom, 1996). The standardized root mean square residual (SRMR) was lower (.02) than the acceptable upper bound of .08. The root mean square error of approximation (RMSEA) showed a good fit value (.063) because it was below the recommended value of .08 (Bentler \& Bonnet, 1980). Second, the adjusted GFI (AGFI) showed a good fit value (.914) because it is greater than .80 (Tanaka \& Huba, 1985). The normed fit index (NFI) showed 960 exceeds the lowest recommended value of .90 (Bollen, 1990). Tucker-Lewis index (TLI) showed a greater value (.962) than the suggested value of .90 and the comparative fit index (CFI) was greater (.976) than the recommended lower bounds of .90 (Bentler \& Bonnet, 1980). Third, the parsimonious goodness of fit index (PGFI) was greater (.742) than the suggested level of 0.5 which indicated a good result. The parsimonious normed fit index (PNFI) and the parsimonious comparative fit index (PCFI) were both higher $(.712, .714)$ than .5 which signified a positive fit model (Mulaik et. al., 1989). All of the fit indexes were acceptable; thus, the analysis of the hypotheses can be continued.

Table 4. Fit indexes

\begin{tabular}{|c|c|c|}
\hline Fit index & Values & $\begin{array}{l}\text { Fit indexes for the } \\
\text { structural model. }\end{array}$ \\
\hline \multicolumn{3}{|c|}{ Absolute fit measures } \\
\hline$x^{2}$ & 118.17 & The lower the better \\
\hline d.f. & 49 & \\
\hline$p$-Value & .000 & $>.05$ \\
\hline$\chi 2 /$ d.f. & 2.41 & $<3$ \\
\hline $\mathrm{GFI}$ & .946 & $>.90$ \\
\hline SRMR & .020 & $<.08$ \\
\hline RMSEA & .063 & $<.08$ \\
\hline \multicolumn{3}{|c|}{ Incremental fit measures } \\
\hline AGFI & .914 & $>.90$ \\
\hline $\mathrm{NFI}$ & .960 & $>.90$ \\
\hline TLI & .967 & $>.90$ \\
\hline $\mathrm{CFI}$ & .976 & $>.90$ \\
\hline \multicolumn{3}{|c|}{$\begin{array}{l}\text { Parsimonious } \\
\text { measures }\end{array}$} \\
\hline PGFI & .742 & $>.50$ \\
\hline PNFI & .712 & $>.50$ \\
\hline PCFI & .724 & $>.50$ \\
\hline
\end{tabular}

\section{Analysis of Structural Model}

The current study has identified that attitude towards behaviour of following the "Stay at Home" orders, subjective norms and perceived behavioural control (PCB) have a positive and strong relationship with behavioural intention to follow the "Stay at Home" orders. The hypotheses effects were assessed using the coefficients. Table 5 shows that attitude toward behaviour has a positive and significant effect on behavioural intention $(\beta=.267, p<.001)$. As a result, $\mathrm{H}^{1}$ is supported. Next, the subjective norms were also indicated a positive and significant effect on behavioural intention adoption $(\beta=.166, p<.05)$. The perceived behaviour control also indicated a positive and significant effect on behavioural intention $(\beta=.261$, $\mathrm{p}<.001)$. Thus, $\mathrm{H}^{2}$ and $\mathrm{H}^{3}$ are supported by the data. The planned behaviour variables in this 
study explained $27 \%$ of the total variance of behavioural intention to follow the "Stay at Home" orders ( $\left.R^{2}=.267\right)$. However, according to Hair et al., $(2011), 0.25<=\left(R^{2}\right) 0.27<0.50$ is considered as weak. Even though the $\mathrm{R}^{2}$ of the current study showed low, but it is still acceptable due to novel research in Malaysia. The "Stay at Home" study is categorised as health-related behaviour and less study has been done related to this topic.

Table 5: Hypotheses and Results

\begin{tabular}{|l|l|l|l|l|l|l|}
\hline Path & Relationship & $\beta$ & S.E & C.R & $\begin{array}{l}\text {. } \\
\text { value }\end{array}$ & $\begin{array}{l}\text { Hypothesis } \\
\text { Results }\end{array}$ \\
\hline $\mathrm{H}^{1:}$ & $\mathrm{ATB} \rightarrow \mathrm{BI}$ & .267 & .036 & 3.787 & $* * *$ & Supported \\
\hline $\mathrm{H}^{2}:$ & $\mathrm{SN} \rightarrow \mathrm{BI}$ & .166 & .064 & 3.015 & .003 & Supported \\
\hline $\mathrm{H}^{3}:$ & $\mathrm{PCB} \rightarrow \mathrm{BI}$ & .261 & .059 & 3.589 & $* * *$ & Supported \\
\hline
\end{tabular}

$* * * p<.001, p<.05$

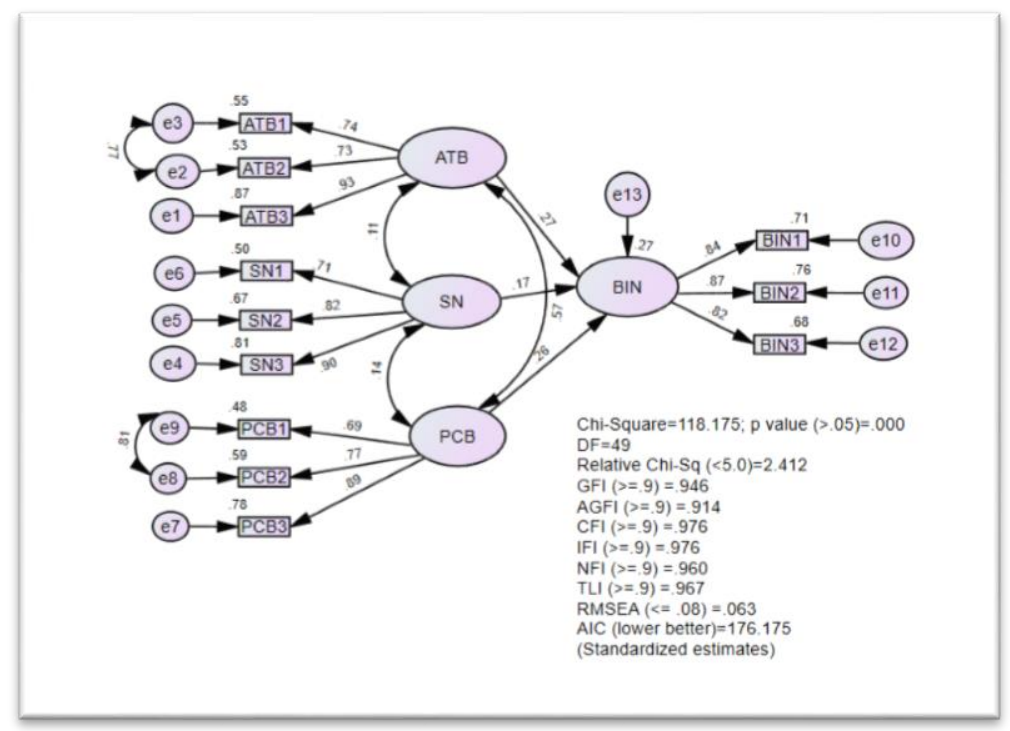

\section{Discussion}

The survey has shown that majority relied on the Telegram application on smartphones which the content was developed by the Malaysian National Security Council (NSC) to get the latest information on COVID-19. The news or information of COVID-19 on Twitter, Facebook, or any other platform on OTT services gave beneficial effects to users. A study was done by Latiff, et al., (2019) on the unique attributes of internet television in students' learning experience showed that streaming news and current issues can be part of the educational approach. It can be seen that internet television falls under OTT services. The unique attributes of internet television such as content, cost and technology attract people to adopt and use. The use of OTT services during the COVID-19 pandemic is a good strategy in handling this issue. Therefore, the more users use OTT services for COVID-19 information, the more citizens will be alert on the SOP especially the "Stay at Home" orders.

The first variable that is the attitude towards behaviour of following the "Stay at Home" orders during the COVID-19 outbreak showed a positive and significant effect on behavioural intention to follow the order or orders. According to the theory of planned behaviour, if a person sees a behaviour following the "Stay at Home" orders as positive behaviour, he or she is likely to implement them. Thus, this finding is consistent with this 
theory. This study was also similar to previous research done by Micheal et al., (2020) in their study on "Safer at Home" orders. Besides, Zhang et al., (2019) and Kim et al., (2018) also showed a positive and significant relationships in their studies on health-related behaviour. In other words, citizens should be mindful of and believe that staying at home throughout the COVID-19 outbreak is good and beneficial. In addition, the campaigns held by the government or Ministry of Health across the media especially the OTT services is a good strategy in convincing the importance of following the "Stay at Home" orders.

The second variable that is subjective norms showed a positive and significant effect on the behavioural intention to follow the "Stay at Home" orders. If a person feels social pressure to comply with such a policy or orders, he or she is likely to follow it. The finding is competent with the theory of planned behaviour and similar studies such as Micheal et al., (2020) and Sumaedi et al, (2020); internet technology adoption such as Ilham and Kamariah (2012); Safeena et al., (2013) and hiring disabilities (Magdalene et al., 2015). Therefore, appointing a public figure to create credible messages and behaviours to citizens in order to follow the "Stay at Home" orders is a good approach by the government and responsible parties.

The last variable confirmed that perceived behaviour control has a positive and significant effect on the behavioural intention to follow the "Stay at Home" orders. A person tends to engage in a specific behaviour when he or she was in control. When citizens realize that they had been controlled, they would be more willing to commit such behaviour. With reference to the COVID-19 cases, if citizens have the resources to "Stay at home" and do not see any major obstacles to doing so, thus they tend to follow the "Stay at Home" orders. This finding is consistent with previous findings using the same theory (Ates, 2019; Micheal et al., 2020; Zhang et al., 2019). Therefore, based on these findings, the government or responsible parties have ensured that citizens always feel in control. As mentioned earlier, in order to make citizens feel in control, life must be secured, and obstacles must be substantially removed.

\section{Conclusion}

As COVID-19 is a global pandemic, we should address it wisely. Before all Malaysian citizens get fully vaccinated, the best thing to do is to prevent and avoid being vulnerable to COVID19 threats. The government is trying to flatten the COVID-19 curve by advising citizens to follow the SOP including the "Stay at Home" orders. Nevertheless, limited study has been conducted regarding this topic. This research has used the theory of planned behaviour to investigate people's behaviour to the new orders that is the intention to follow the "Stay at Home" orders. Thus, this study managed to fill the gap based on the variable tested in this theory.

Overall, the findings reported that behavioural intention to follow the "Stay at Home" orders throughout the COVID-19 outbreak is positively and significantly affected by the attitude towards behaviour, subjective norm, and perceived behavioural control. It is almost two years since COVID-19 hit Malaysia and the government has announced massive information, campaign, using public figures to continuously inform people and importantly to ensure people's life. The Telegram application by the NSC helps the citizens to update their knowledge and information about COVID-19. As mentioned in the past studies and literature 
review, people's intention will determine their behaviour. The higher intention will result in a higher probability of creating behaviour. Thus, this paper was designed appropriately to investigate the factors that influence citizens' intention to follow the "Stay at Home" orders. This paper contributes or offers new ways for researchers to investigate health behaviours by using the mobile technology such as OTT services among the citizens. The framework that applied the theory of Planned Behaviour may help researchers in developing future research models in greater and vigorous ways.

\section{Corresponding Author}

Dzaa Imma Abdul Latiff (Senior Lecturer)

Faculty of Communication and Media Studies

Universiti Teknologi MARA, Cawangan Negeri Sembilan, Kampus Rembau, 71300 Rembau.

Email: dzaa17@uitm.edu.my

\section{References}

Abdul Rashid. (2021). Senior citizens would disobey the quarantine will be compound. Retrieved from https://www.kosmo.com.my/2021/05/06/warga-emas-dikompaunlanggar- arahan-kuarantin/

Ajzen, I. (2002), Perceived behavioral control, self-efficacy, locus of control, and the theory of planned behaviour, Journal of Applied Social Psychology, Vol. 32 No. 4, pp. 665-683.

Ajzen, I. (1991), "The theory of planned behavior", Organizational Behavior and Human Decision Processes, Vol. 50 No. 2, pp. 179-211, doi: 10.1016/0749-5978(91)90020-T.

Ajzen, I. (1985). From intentions to actions: A theory of planned behavior BT - action control: From cognition to behavior. In Kuhl, J. and Beckmann, J. (Eds.), Action control: From cognition to behavior, p. 11-39. Berlin, Heidelberg: Springer Berlin Heidelberg.

Ali, A., Xiaoling, G., Sherwani, M., Ali, A. (2017. Factors affecting Halal meat purchase intention evidence, from international Muslim. British Food Journal 119(3): 527-541

Awang, A. (2021). An 18 -year -old teenager was fined RM3000. Retrieved from https://www.bharian.com.my/berita/kes/2021/04/805832/remaja-18-tahun-kenakompaun- rm3000

Ates, H. (2019). Elementary school teachers' behavioral intentions for healthy nutrition: extending theory of planned behavior, Health Education, Vol. 119 No. 2, pp. 133-149, doi: 10.1108/HE-11-2018-0056.

Azjen, I., \& Fishbein, M. (1980) Understanding attitude and predicting social behavior, PrenticeHall, Englewood Cliffs, NJ.

Bao, Y., Hoque, R., \& Wang, S. (2017), "Investigating the determinants of Chinese adult children's intention to use online health information for their aged parents", International Journal of Medical Informatics, Vol. 102, pp. 12-20, doi: 10.1016/j.ijmedinf.2017.01.003.

Bernama. (2020). Summons an individual who violates a movement control order. Retrieved from https://www.bernama.com/bm/news.php?id=1822848

Bollen, K. A. (1990). Overall fit in covariance structure models: two types of sample size effects. Psychological Bulletin, 107(2), 256-259.

Close, M. A., Lytle, L. A., Chen, D. G., \& Viera, A. J. (2018), "Using the theory of planned behavior to explain intention to eat a healthful diet among Southeastern United States office workers", Nutrition and Food Science, Vol. 48 No. 2, pp. 365-374, doi: 10.1108/NFS-06-2017-0123. 
Fan, Y., Zhang, S., Li, Y., Li, Y., Zhang, T., Liu, W., \& Jiang, H. (2018). Development and psychometric testing of the Knowledge, Attitudes and Practices (KAP) questionnaire among student Tuberculosis (TB) Patients (STBP-KAPQ) in China. BMC Infect Dis. 18(1). Retrieved from http: 10.1186/s12879-018-3122-9

Fornell \& Larcker. (1981), Evaluating structural equation models with unobservable measurement error. Journal of Marketing Research, 48, 39-50. variables and

Hilmi, H. M. N. (2021). Covid-19: 4,140 cases, 44th highest death to date. Retrieved from https://www.hmetro.com.my/utama/2021/05/706224/covid-19-4140-kes-44-

kematian-

tertinggi-setakat-ini

Hair. (2010), Hair, J.F., Black, W.C., Babin, B.J. \& Anderson, R.E. (2010), Multivariate data analysis. $A \quad$ global perspective, 7th ed., Pearson Education, New Jersey.

Hair, J. F., Ringle, C. M., \& Sarstedt, M. (2011). PLS-SEM: Indeed a silver bullet. Journal Of Marketing Theory and Practice, 19(2), 139-152

Ilham and Kamariah. (2012). Examining a theory of planned behavior (TPB) and technology acceptance model (TAM) in internet purchasing using structural equation modelling. Journal of Arts, Science \& Commerce. Vol.- III, Issue 2(2), April 2012 [62]

Joreskog, K. G., \& Sorbom, D. (1996). “ LISREL8 User's reference Guide. SSI.

Guo, M. (2020) Examining the Chinese public's awareness and reaction to the coronavirus. Retrieved from https://us.kantar.com/business/health/2020/health-awareness-andbehaviors-during-covid-19-epidemic/

McEachan, R. R. C., Conner, M., Taylor, N. J., \& Lawton, R. J. (2011), "Prospective prediction of health- related behaviors with the theory of planned behavior", Health Psychology Review, Vol. 5 No. 2, pp. 97-144, doi: 10.1080/17437199.2010.521684.

Media Partners Asia. (2020). Coronavirus Gives 60\% Boost to Mobile Streaming in Southeast Asia https://variety.com/2020/streaming/asia/coronavirus-boost-mobilestreaming-southeast- asia-1234584706/

Micheal, A. C., Daniel, D. C., \& Charles, S. (2020). Older adults' intention to socially isolate once COVID-19 Stay-at-Home orders are replaced with "Safer-at-Home" public health advisories: A survey of respondents in Maryland. Journal of Applied Gerontology 2020, Vol. 39 (11) 1175-1183 DOI: 10.1177/0733464820944704

MOH COVID-19 Official Website. (2021). Ten (10) new clusters were reported today 12/04/2021. Retrieved from https://covid19.moh.gov.my/sorotan/2021/04/sepuluh10-kluster-baharu- dilaporkan-hari-ini-12042021

MOH COVID-19 Official Website. (2021). Update state COVID19 in Malaysia up to 15042021. Retrieved from https://covid-19.moh.gov.my/terkini-negeri/2021/04/kemaskininegeri- covid-19-di-malaysia-sehingga-15042021

MOH COVID-19 Official Website (2021). Update state COVID19 in Malaysia up to 26062021. Retrieved from https://covid-19.moh.gov.my/terkini/2021/06/situasi-terkini-covid-19di- $\quad$ malaysia-21062021

MOH COVID-19 Official Website. (2021). Update state COVID19 in Malaysia up to 24052021. Retrieved from https://covid-19.moh.gov.my/terkini-negeri/2021/05/kemaskininegeri-covid-19-di-malaysia-sehingga-24052021

Nielson. (2021). Top 5 streaming platforms in Malaysia. Retrieved form https://themalaysianreserve.com/2021/01/05/top-5-streaming-platforms-inmalaysia/ 
Peters, R. M., \& Templin, T. M. (2010), "Theory of planned behavior, self-care motivation, and blood pressure self-care", Research and Theory for Nursing Practice Vol. 24 No. 3, pp. 172-186.

Population Hub. (2021). Retrieved from Population of Klang 2021 | Klang population statistics (population-hub.com)

Zuki, R. M. (2021). PKPD di beberapa lokaliti di 5 negeri. Retrieved from https://www.bharian.com.my/berita/nasional/2021/05/821820/pkpd-di-beberapalokaliti-di-5- negeri-bermula-ahad

Sumaedi, S., Bakti, I. G. M. Y., Rakhmawati, T., Widianti, T., Astrini, N. J., Damanyati, S., Massijaya, M. A., \& Jati, R. K. (2020). Factors influencing intention to follow the "stay at home" policy during the COVID-19 pandemic. International Journal of Health Governance. Emerald Publishing Limited. 2059-4631. DOI 10.1108/IJHG-05-2020-0046

Sumaedi, S., Yarmen, M., Bakti, I. G. M. Y., Rakhmawati, T., Astrini, N., \& Widianti, T. (2016), "The integrated model of theory planned behavior, value, and image for explaining public transport passengers' intention to reuse", Management of Environmental Quality, Vol. 27 No.2, pp. 124- 135, doi: 10.1108/MEQ-03-2015-0027.

Tanaka, J. S., \& Huba, G. J. (1985). A fit index for covariance structure models under arbitrary GLS estimation. British Journal of Mathematical and Statistical Psychology 38: 197-201

Zhang, X., Liu, S., Wang, L., Zhang, Y., \& Wang, J. (2019), “Mobile health service adoption in China: integration of theory of planned behavior, protection motivation theory and personal health differences", Online Information Review, Vol. 44 No. 1, pp. 1-23, doi: 10.1108/OIR-11- 2016- 0339. 